\title{
Analysis of Combustion Gas Properties According to Combustion of Wood Materials Based in Korea
}

\section{PARK, Young-Ju}

Dept. of Fire \& Emergency Management, Kangwon National University | Laboratory of Forest Resources Management, Division of Forest Environmental Sciences, Department of Agro-

Environmental Sciences, Faculty of Agriculture, Kyushu University

\section{LEE, Si-Young}

Professional Graduate School of Disaster Prevention, Kangwon National University | Laboratory of Forest Resources Management, Division of Forest Environmental Sciences, Department of AgroEnvironmental Sciences, Faculty of Agriculture, Kyushu University

Kim, Jong-Buk

Professional Graduate School of Disaster Prevention, Kangwon National University | Laboratory of Forest Resources Management, Division of Forest Environmental Sciences, Department of AgroEnvironmental Sciences, Faculty of Agriculture, Kyushu University

\section{OHGA, Shoj i}

Laboratory of Forest Resources Management, Division of Agro-environmental Sciences, Department of Forest Environmental Sciences, Faculty of Agriculture, Kyushu University

https://doi.org/10.5109/1955379

出版情報：九州大学大学院農学研究院紀要. 63 (2)，pp.191-199，2018-09-01. Faculty of Agriculture, Kyushu University

バージョン :

権利関係 : 


\title{
Analysis of Combustion Gas Properties According to Combustion of Wood Materials Based in Korea
}

\author{
Young-Ju PARK ${ }^{1}$, Si-Young LEE ${ }^{2}$, Jong-Buk Kim ${ }^{3}$ and Shoji OHGA* \\ Laboratory of Forest Resources Management, Division of Forest Environmental \\ Sciences, Department of Agro-Environmental Sciences, Faculty of Agriculture, \\ Kyushu University, Fukuoka 811-2415, Japan \\ (Received March 22, 2018 and accepted May 8, 2018)
}

\begin{abstract}
To assess the hazards of the gases emitted by the combustion of building materials, this study analyzed the gases produced through the combustion of four wood materials - slash pine, lauan, cedar and pine using an FTIR spectrometer and cone calorimeter. The analysis shed light on the distinct structures of the carbonated parts, which were attributable to the differences in wood types, distribution density (specific gravity) of medullary rays and water content among the species of trees. As for the gas emissions by the combustion of wood materials, all the materials tested here were characterized by substantial carbon dioxide $\left(\mathrm{CO}_{2}\right)$ emissions. Particularly, $\mathrm{CO}_{2}$ emissions by slash pine and lauan amounted to $373,149.9 \mathrm{ppm}$ and $310,142.5 \mathrm{ppm}$, or 3.7 and 3 times higher than its lethal concentration (Cf) 100,000 ppm, respectively.

The nitrogen dioxide $\left(\mathrm{NO}_{2}\right)$ emissions by slash pine $(1,265.303 \mathrm{ppm})$, lauan $(881.791 \mathrm{ppm})$ and pine $(315.75 \mathrm{ppm})$ also exceeded its lethal concentration (Cf) $250 \mathrm{ppm}$. The sulfur dioxide $\left(\mathrm{SO}_{2}\right)$ emissions by the four wood materials significantly exceeded its lethal concentration $400 \mathrm{ppm}$ with slash pine, lauan, pine and cedar emitting 2,485.306 ppm, $1,743.776 \mathrm{ppm}, 654.921 \mathrm{ppm}$ and $585.816 \mathrm{ppm}$, respectively. The CO concentration in slash pine was $7,021.683 \mathrm{ppm}$, whilst those of the others were below the lethal concentration (Cf) 4,000 ppm. Notably, all the materials emitted much nitrogen dioxide $\left(\mathrm{NO}_{2}\right)$ and sulfur dioxide $\left(\mathrm{SO}_{2}\right)$ as well as $\mathrm{CO}_{2}$ and $\mathrm{CO}$ like most wood materials. The findings of this study are noteworthy as the reference data for assessing the health hazards of other building materials in future studies.
\end{abstract}

Key words: Wood Materials, Combustion Properties, Combustion gas, nitrogen dioxide, carbon monoxide, carbon dioxide, cone calorimeter, Lethal concentration

\section{INTRODUCTION}

An increasing number of skyscrapers and complex buildings in tandem with the compressed economic and industrial growth of Korea and the resultant use of various energy sources have inevitably engendered the factors that influence fires. As of 2016, a total of 43,413 fires broke out causing 2,024 casualties (306 killed and 1,718 injured) and KRW 420.6 billion in damage. Among the foregoing figures, 11,541 residential buildings including apartment units and detached houses were gutted by fires (26\% of all fires), which left 193 deaths (63\%) and 691 injuries (40\%) and caused KRW 48 billion in damage (11\%) (Fire Statistical Yearbook, 2016). Meanwhile, a wide range of newly developed high-quality building materials by virtue of ever-evolving engineering technologies are available now. According to Kwon (Kwon, H. S., 2011) the easy and rapid burning behavior of interior and finishing materials used for buildings intended to meet people's needs for aesthetics shortens the time taken for combustion to extend, increasing the toxic gas

Dept. of Fire \& Emergency Management, Kangwon National University, Samcheok-Si, Gangwon-Do 245-711, Republic of Korea

${ }^{2}$ Professional Graduate School of Disaster Prevention, Kangwon National University, Samcheok-Si, Gangwon-Do 245-711, Republic of Korea

${ }^{3}$ Professional Graduate School of Disaster Prevention, Kangwon National University, Samcheok-Si, Gangwon-Do 245-711, Republic of Korea

* Corresponding Author (E-mail: ohga@forest.kyushu-u.ac.jp) emissions, which results in loss of life. It has been welldocumented that the loss of life in buildings exposed to fires is mostly associated with the secondary damage resulting from 'smoke and toxic gases' rather than the direct 'thermal burn.'

In the same vein, it is crucial to assess the hazards of wood materials among other interior materials indispensable for buildings including their toxicity in relation to their combustion properties. The fire accidents in Korea where the inhalation of hazardous gases and the heat released by fires caused casualties include the bar fire in Inhyeondong Incheon in 1999 (56 deaths and 78 injuries) and the Jungangro Station fire on a subway train in Daegu City in 2003 (192 dead, 21 missing and 151 injured). Also, in 2008, the fire that broke out at Korea 2000's cold-storage warehouse located in Hobeopmyeon Icheon Gyeonggido killed 40 workers. The foregoing cases resulted in fatalities related to building interior materials that served as risk factors, whose hazards need be determined by taking into account such elements as ignitability, combustibility, heat released from burning materials, rate of heat generation, smoke and gas emissions (Cho N. W., et al., 2012). In that smoke and toxic fumes are the main causes of deaths from suffocation and of the failure to evacuate, smoke concentration and hazardous gases are important elements that must be analyzed. Among the gases produced by the combustion of many materials used for the interior and exterior of buildings, carbon dioxide $\left(\mathrm{CO}_{2}\right)$, carbon monoxide $(\mathrm{CO})$, hydrogen bromide $(\mathrm{HBr})$, hydrogen chloride $(\mathrm{HCl})$, sulfur dioxide $\left(\mathrm{H}_{2} \mathrm{~S}\right)$, nitrogen dioxide $\left(\mathrm{NO}_{2}\right)$ and ammonia 
$\left(\mathrm{NH}_{3}\right)$ are known as major hazardous and even deadly gases (Kim J. B., S. Y. Lee 2016). Many researchers assessed the hazards of exterior and interior materials for buildings.

A study measured the mean duration of inactivity in mice inhaling toxic combustion gases such as hydrogen chloride $(\mathrm{HCl})$, hydrogen fluoride $(\mathrm{HF})$, hydrogen cyanide $(\mathrm{HCN})$ and sulfur dioxide $\left(\mathrm{SO}_{2}\right)$ (Cho N. W., et al., 2012). Another study used the FTIR (Fourier Transform Infrared) spectrometer to analyze 14 combustion gases (i.e. carbon monoxide, carbon dioxide, acetic acid, butyl acetate, ethylene, methane, nitrogen dioxide, ammonia, hydrogen fluoride, sulfur dioxide, hydrogen bromide, methanol, hydrogen chloride and nitrogen monoxide) emitted by local coniferous pine (Pinus densiflora) and deciduous oriental oak (Quercus variabilis) leaves, and reported the inhalation of carbon monoxide and carbon dioxide, which accounted for over 99\% of the entire gas emissions by leaves subject to the smoldering ground combustion in wild fires, was highly hazardous to health (Kim D. H., et al., 2009). A third study demonstrated carbon dioxide $\left(\mathrm{CO}_{2}\right)$, hydrogen bromide $(\mathrm{HBr})$, hydrogen chloride $(\mathrm{HCl})$, nitrogen dioxide $\left(\mathrm{NO}_{2}\right)$, sulfur dioxide $\left(\mathrm{SO}_{2}\right)$, carbon monoxide $(\mathrm{CO})$ and ammonia $\left(\mathrm{NH}_{3}\right)$ produced by the combustion of five interior finishing materials used for houses or warehouses - edge glued panels, MDF, softwood plywood, core plywood, treated lauan had deadly effects on human body as part of an assessment of combustion toxicity of composite woods, and provided some reference data for further studies on the selection of building materials and relevant hazards (Kim J. B., S. Y. Kim, 2016). A fourth study analyzed the fumes emitted by the combustion of wood materials such as MDF and two types of treated lauan wood and four chemical materials such as flame resistance styrofoam, styrofoam, urethane foam and plaster boards, and found high health risks, if inhaled, with MDF producing 795-ppm $\mathrm{NH}_{3}$ (lethal concentration:750 ppm) and treated lauan wood emitting 256,965-ppm $\mathrm{CO}_{2}$, which was 2.5 times higher than its lethal concentration $100,000 \mathrm{ppm}$ (Kim J. B., S. Y., Lee, 2016). Also, in assessing the hazards of combustion gases produced by plywood, interior finishing wood (Yoruba:pine), compressed styrofoam insulation materials, laminate floor and five PVC linoleums widely used for the interior of buildings, Seo et al. (Swo H, J., D. W. Son, 2015) confirmed the CO emission by the compressed styrofoam insulation material reached 6,098 ppm, exceeding its lethal concentration 4,000 ppm, and reported the toxicity indices were 5.19 (plywood), 4.13 (PVC linoleum), 2.35 (compressed styrofoam insulation), 2.34 (laminate floor) and 1.22 (interior finishing wood), suggesting the combustion gases, if inhaled, could lead to fatalities.

The FTIR spectrometer data are qualitative and quantitative measurements of combustion gases. Currently, the fire safety performance of building interior materials in Korea is assessed in compliance with the Ministry of Land, Transport and Maritime Affairs' Notification No. 2011-39 involving the heat release rate test (KS F ISO 5660), incombustibility test (KS F ISO 1182) and gas hazard test (KS F 2271) (KS F 2271, 1998). The cone calorimeter and FTIR (Fourier Transform Infrared) spectrometer lend themselves to the quantitative and qualitative analysis of heat release rates and combustion gas emissions. Thus, focused on the secondary damage due to combustion gases emitted by building materials, this study analyzed hazardous combustion gas emissions by four interior wood materials, i.e. slash pine, lauan, cedar and pine, and assessed their hazards in reference to the lethal concentration of each gas to provide some reference data for future studies on hazard assessment.

\section{MATERIALS AND METHODS}

\section{Materials and experiment}

The wood materials of interest in this study were collected in inhabited houses in Yangju Gyeonggido. The humidifying conditions were not considered to maximize the real status of the materials.

An FTIR spectrometer connected to a cone calorimeter was used to analyze the combustion properties of the gases emitted by the four materials - slash pine, lauan, cedar and pine - used for housings. Different thicknesses

Table 1. Characteristics of Wood Species

\begin{tabular}{|c|c|c|c|}
\hline Tree species & Density & General properties of materials & Usage \\
\hline Donglas fir & 0.54 & $\begin{array}{l}\text { - The material is soft and resistant. } \\
\text { - Pine rosin is relatively cheap and cheap. } \\
\text { - It is easy to process and you can get a lot of } \\
\text { materials. }\end{array}$ & $\begin{array}{l}\text {-General structural materials such as pillars, beams, } \\
\text { roofs, and furniture. }\end{array}$ \\
\hline Lauan & 0.65 & $\begin{array}{l}\text { - The material is uniform and durable. } \\
\text { - The grain is beautiful and easy to process. } \\
\text { - There is no fault of knots or the like. }\end{array}$ & $\begin{array}{l}\text {-Structural materials, furniture materials, water } \\
\text { materials, window materials, equipment materials, } \\
\text { plywood }\end{array}$ \\
\hline $\begin{array}{l}\text { Cryptomeria } \\
\text { japonica }\end{array}$ & 0.39 & $\begin{array}{l}\text { - The wood is straight and light. } \\
\text { - It is easy to work with soft material, but it is easy } \\
\text { to split. } \\
\text { - Less resin, strong in water and moisture. }\end{array}$ & $\begin{array}{l}\text {-High-grade building materials, foundation, } \\
\text { furniture, utensil, pile, sleeper, ship, sculpture. }\end{array}$ \\
\hline Pinus densiflora & 0.45 & $\begin{array}{l}\text { - High resin and high durability. } \\
\text { - The grain is rough and hard. }\end{array}$ & $\begin{array}{l}\text {-Construction material, soil wood, pile, packing, } \\
\text { box. }\end{array}$ \\
\hline
\end{tabular}


and weights of these materials were tested. Table 1 (Moon Y. S., S. R. Park, 2016) outlines the properties of the materials used here.

\section{Specimens and analysis}

The four wood materials used for building interior materials, i.e. slash pine, lauan, cedar and pine, underwent the heat release rate test (KS F ISO 5660-1) in compliance with the Korea Fire Equipment Inspection Corporation's accredition criteria and the Ministry of Land, Transport and Maritime Affairs' Notification No. 2011-39, "Incombustibility Performance Criteria for Finishing Materials for Buildings". As per the criteria, slash pine, lauan, cedar and pine specimens of different thicknesses and weights were prepared (Table 2). An FTIR spectrometer (Midac, US/14001) and a cone calorimeter (Fire testing technology, GB/Dual Cone 2000) were used to analyze the combustion gas emissions by each material in three trials.

Table 2. Descriptions of Material for Cone Calorimeter

\begin{tabular}{ccc}
\hline Materials & Thickness [mm] & Weight [g] \\
\hline Donglas fir & 3.8 & 144.4 \\
Lauan & 21 & 112.0 \\
Cryptomeria japonica & 12 & 40.6 \\
Pinus densiflora & 11 & 52.5 \\
\hline
\end{tabular}

\section{Analyzing general properties of materials}

Wood materials used for buildings are mostly side grain surface cutting boards. Here, the selected wood materials were quarter-sawn boards cut with the growth rings being perpendicular to the board surface (Jung $\mathrm{H}$. S., et al., 2005). The heating intensity of the cone calorimeter was set at $50 \mathrm{~kW} / \mathrm{m}^{2}$. The specimens were observed approximately 180s after complete combustion following the generation of flames. The entire area of slash pine heated and burnt was inflated, which seemed attributable to the relatively thin specimen prolonging the exposure of wood tissues to heat.

The thicker and denser lauan better resisted the heat, with carbonization occurring in a certain direction along with the grains of tissues (Figure 1). Upon being heated at 450 or over, all volatile substances in the wood evaporate with $1520 \%$ of it left as char, which varies with the lignin content. The char blocks oxygen, slowing down the rate of combustion (Pearce F. M., et al., 1981).

The cedar and pine, exposed to the high-temperature heat, underwent accelerated carbonization. In particular, the pine was characterized by multiple large carbonized tissues. The rate of carbonization is dependent on lots of variables, e.g. the types of wood, water content, heat penetration and thermal property (Spearpoint M. J., 1999). The differences in post-combustion properties among slash pine, lauan, cedar and pine seemed to result from the differences in the types of wood, distribution density (specific gravity) of medullary rays, and water content.

\section{Analyzing gas emissions and types}

The pollutants inside the FTIR spectrometer were removed with dry nitrogen gas $\left(\mathrm{N}_{2}\right)$. Then, the spectrometer was initialized at 1 atmosphere $(1013 \mathrm{kPa})$. The gas cell was protected with a $0.2-\mu \mathrm{m}$ filter. The line length and the suction pump flux were set at $2.0 \mathrm{~m}$ and $5.0 \mathrm{~m} / \mathrm{min}$, respectively. The status of the standard absorption wavelength range was viewed on the computer linked to the FTIR spectrometer. The test and analysis were conducted with moisture and $\mathrm{CO}_{2}$ completely removed. The $\mathrm{CO}_{2}, \mathrm{HBr}, \mathrm{HCl}, \mathrm{NO}_{2}, \mathrm{SO}_{2}, \mathrm{NH}_{3}$ and $\mathrm{CO}$ concentrations in the slash pine, lauan, cedar and pine materials were measured for each time slot (Figure 2 Figure 8).

As shown in Figure 9 Figure 12, the qualitative and quantitative analysis results were plotted on the spectral graphs of $\mathrm{CO}_{2}, \mathrm{HBr}, \mathrm{HCl}, \mathrm{NO}_{2}, \mathrm{SO}_{2}, \mathrm{NH}_{3}$ and $\mathrm{CO}$ per wood material. Based on the spectrum specific to each gas in the FTIR spectrometry, the graphs of the test data were compared to find out if they matched their corresponding peaks for the qualitative analysis. The $\mathrm{X}$ and $\mathrm{Y}$ axes indicate the absorption (wavenumbers, $\mathrm{cm} \mu^{-1}$ ) wavelength range and absorbance, respectively.

The tested gas-specific absorption wavelength ranges were compared with the unique peaks (EPA FTIR Spectra regions data) specified in the U.S. Environmental Protection Agency's (EPA) Bands Classification. The

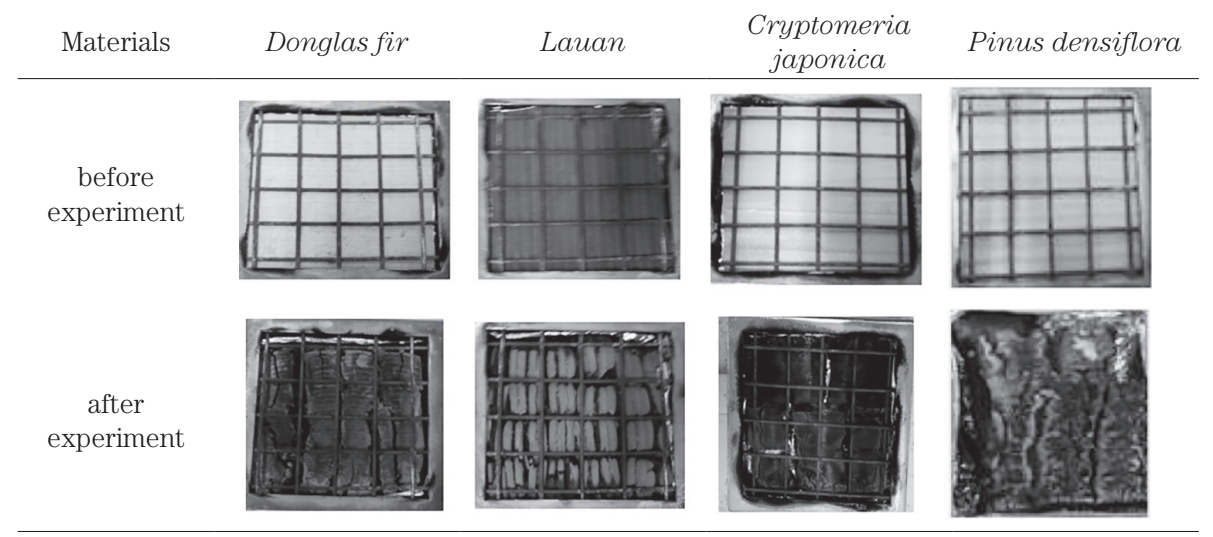

Fig. 1. Photograph specimen of of wood materials based. 


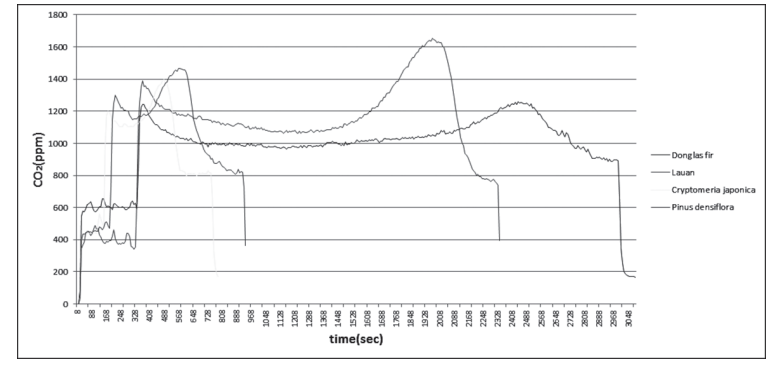

Fig. 2. Concentration curve of $\mathrm{CO}_{2}$ for each material.

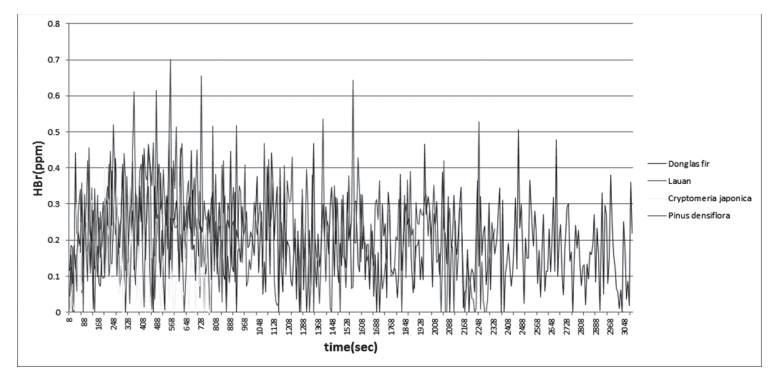

Fig. 3. Concentration curve of $\mathrm{HBr}$ for each material.

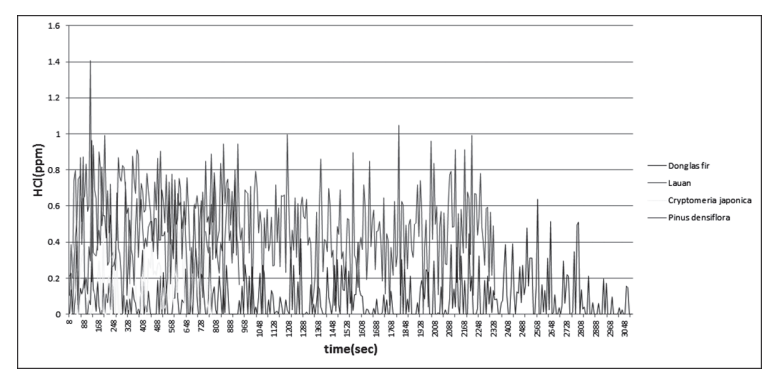

Fig. 4. Concentration curve of $\mathrm{HCl}$ for each material.

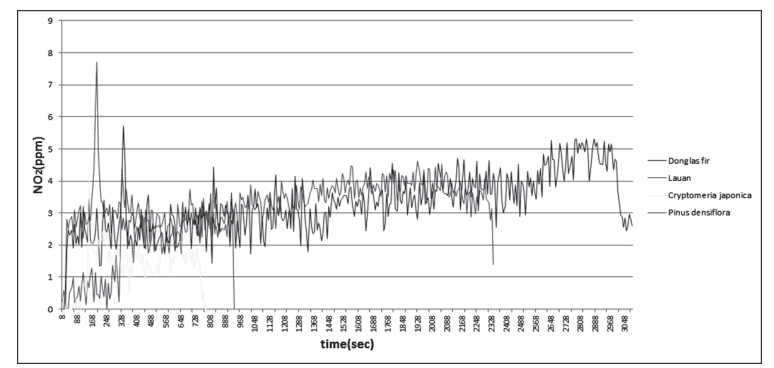

Fig. 5. Concentration curve of $\mathrm{NO}_{2}$ for each material.

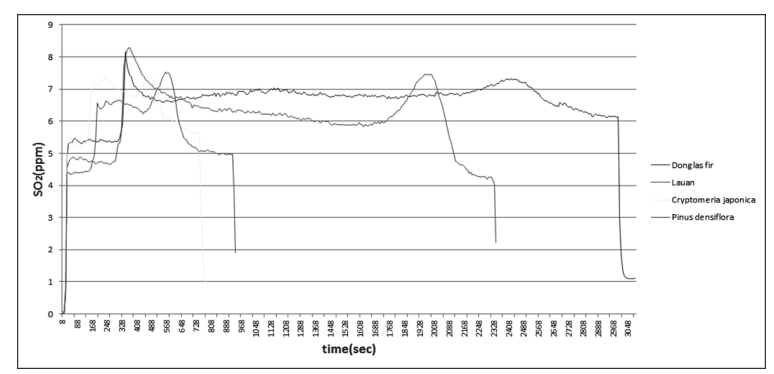

Fig. 6. Concentration curve of $\mathrm{SO}_{2}$ for each material.

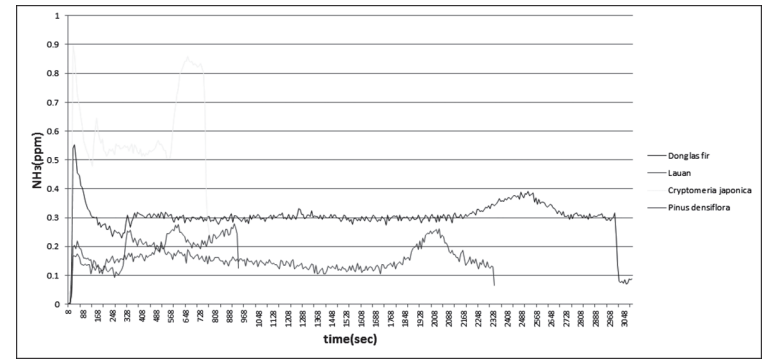

Fig. 7. Concentration curve of $\mathrm{NH}_{3}$ for each material.

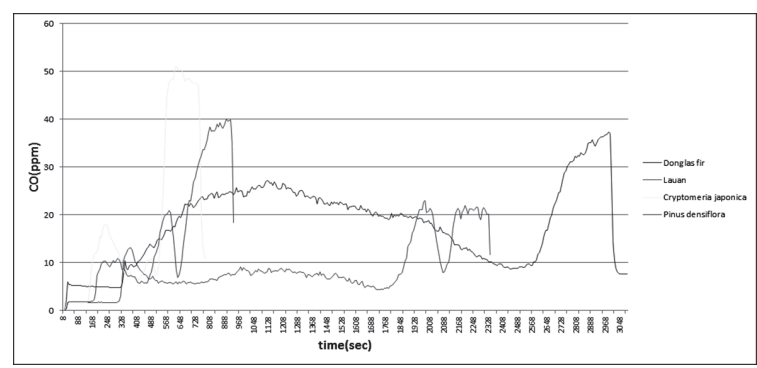

Fig. 8. Concentration curve of $\mathrm{CO}$ for each material.

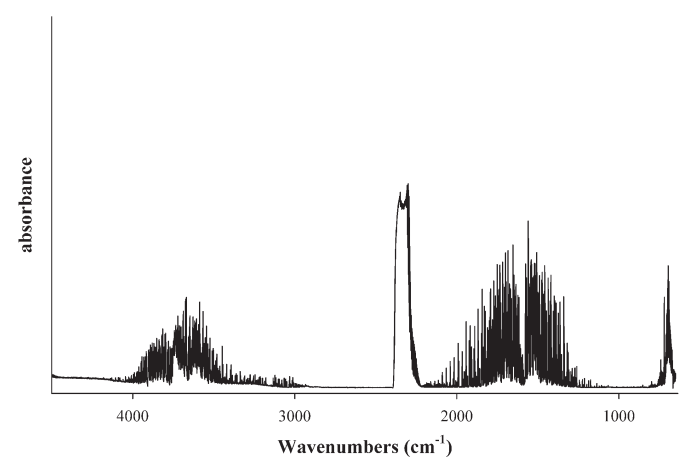

Fig. 9. Combustion gases spectrum of Donglas fir.

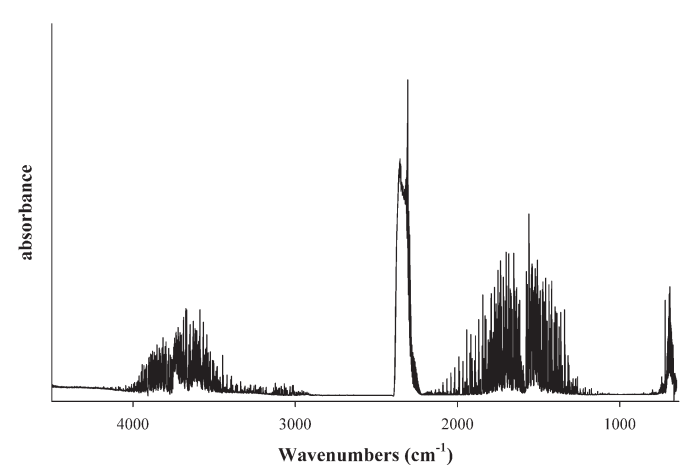

Fig. 10. Combustion gases spectrum of Lauan. 
comparison results are shown in the FTIR Spectra regions data in Figure 13.

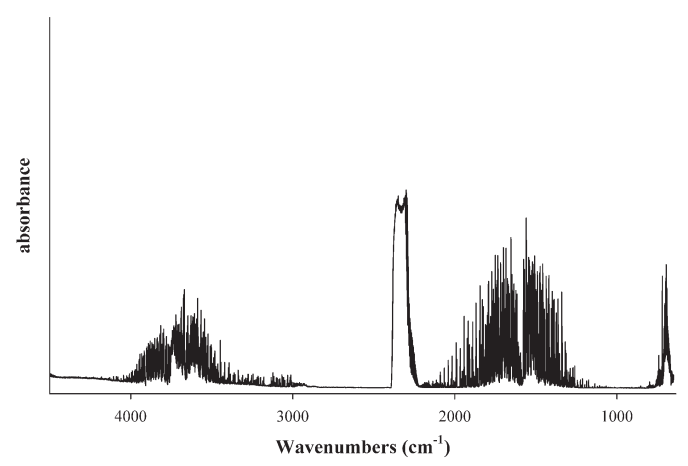

Fig. 11. Combustion gases spectrum of Cryptomeria japonica.

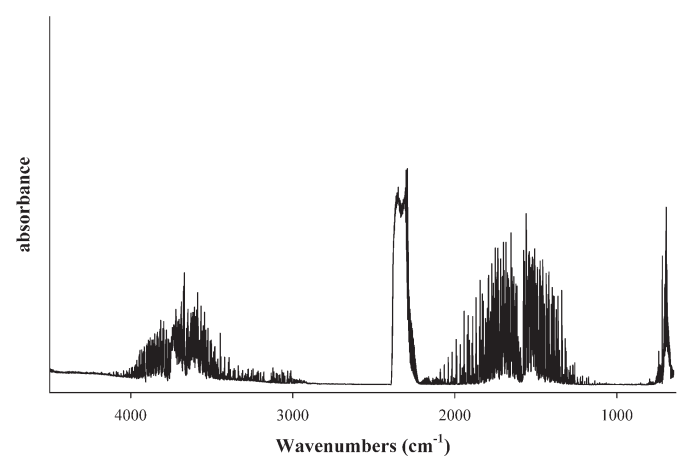

Fig. 12. Combustion gases spectrum of Pinus densiflora.

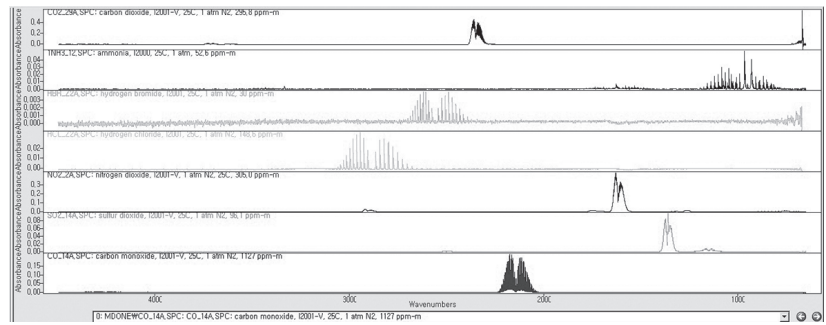

Fig. 13. FT-IR calibration spectra of combustion gases.

\section{RESULTS AND DISCUSSION}

\section{Analyzing hazards of materials}

Table 4 shows the toxicity indices of the materials based on the analysis of $\mathrm{CO}_{2}, \mathrm{HBr}, \mathrm{HCl}, \mathrm{NO}_{2}, \mathrm{SO}_{2}, \mathrm{CO}$ and $\mathrm{NH}_{3}$. Based on the EPA FTIR Spectra regions data (Figure 13) relevant to the unique peak of each gas and Table 3 (ISO DIS 19702), the total $\mathrm{CO}_{2}$ emissions of the materials were comparatively analyzed (Figure 14). The $\mathrm{CO}_{2}$ emissions by slash pine and lauan were 373,149.9 ppm and 310,142.5 ppm, or 3.7 and 3 times higher than its lethal concentration (Cf) 100,000 ppm, respectively. The $\mathrm{CO}_{2}$ emission of pine was $114,466.1 \mathrm{ppm}$, exceeding its lethal concentration (Cf) $100,000 \mathrm{ppm}$, while that of cedar was 88,212.49 ppm, which was below its lethal concentration (Cf).

Figure 15 compares the hydrogen bromide ( $\mathrm{HBr}$ ) concentrations in the materials. The $\mathrm{HBr}$ concentrations fall within the range of $14.604 \mathrm{ppm} \sim 73.568 \mathrm{ppm}$ (slash pine: $73.568 \mathrm{ppm}$, lauan: $61.534 \mathrm{ppm}$, pine: $30.953 \mathrm{ppm}$, and cedar: $14.604 \mathrm{ppm})$, far below its lethal concentration $150 \mathrm{ppm}$. This finding can be explained by the absence of foreign substances such as chemicals in the four natural building materials.

Figure 16 shows the hydrogen chloride (HCl) emission per material. Notably, the HCI emission by lauan reached $145.918 \mathrm{ppm}$ followed by pine (51.228 ppm), slash pine (33.305 ppm) and cedar (18.249 ppm). The HCI emissions of the four materials were far below its lethal concentration $500 \mathrm{ppm}$. This finding indicates natural materials contain small amounts of hydrogen chloride as well as the chemicals including hydrogen bromide aforementioned. Figure 17 shows the nitrogen dioxide $\left(\mathrm{NO}_{2}\right)$ emissions by slash pine (1,265.30 ppm), lauan (881.791 ppm), pine (315.75 ppm) and cedar (132.62 ppm). The $\mathrm{NO}_{2}$ emissions by lash pine and lauan were five and three times higher than its lethal concentration 250 ppm, respectively. Also, the $\mathrm{NO}_{2}$ emission by pine slightly exceeded the lethal concentration. In contrast, the $\mathrm{NO}_{2}$ emission by cedar amounted to half the lethal concentration. Figure 18 shows the sulfur dioxide $\left(\mathrm{SO}_{2}\right)$ emissions. The $\mathrm{SO}_{2}$ emissions by slash pine $(2,485.306$ ppm) and lauan (1,743.776 ppm) were approximately 4 6 times higher than the lethal concentration (Cf) 400 ppm. Though to a lesser extent, the $\mathrm{SO}_{2}$ emissions by pine and cedar were $654.921 \mathrm{ppm}$ and $585.816 \mathrm{ppm}$,

Table 3. Each Concentrations(ppm)of Gases and Toxicity Index

\begin{tabular}{cccccc}
\hline Division & Donglas fir & Lauan & Cryptomeria japonica & Pinus densiflora & Lethal concentration.Cf(ppm) \\
\hline $\mathrm{CO}_{2}(\mathrm{ppm})$ & $373,149.9$ & $310,142.5$ & $88,212.49$ & $114,466.1$ \\
$\mathrm{HBr}(\mathrm{ppm})$ & 73.568 & 61.534 & 14.604 & 30.953 & 51.228 \\
$\mathrm{HCl}(\mathrm{ppm})$ & 33.305 & 145.918 & 18.249 & 315.75 & 5000 \\
$\mathrm{NO}_{2}(\mathrm{ppm})$ & $1,265.303$ & 881.791 & 132.62 & 654.921 \\
$\mathrm{SO}_{2}(\mathrm{ppm})$ & $2,485.306$ & $1,743.776$ & 585.816 & 21.714 \\
$\mathrm{NH}_{3}(\mathrm{ppm})$ & 116.596 & 45.371 & 57.82 & $1,777.042$ \\
$\mathrm{CO}(\mathrm{ppm})$ & $7,021.683$ & $2,477.809$ & $1,826.369$ & 700 \\
\hline
\end{tabular}


Table 4. Exposure Standards of Chemical and Physical Factors

\begin{tabular}{|c|c|c|c|c|c|c|}
\hline \multirow{3}{*}{$\begin{array}{c}\text { Name of } \\
\text { Hazardous } \\
\text { Substances }\end{array}$} & \multirow{3}{*}{ Formula } & \multicolumn{4}{|c|}{ Occapational exposure limits } & \multirow{3}{*}{$\begin{array}{c}\text { Remark } \\
\text { (CAS number,etc.) }\end{array}$} \\
\hline & & \multicolumn{2}{|c|}{ TWA } & \multicolumn{2}{|c|}{ STEL } & \\
\hline & & ppm & $\mathrm{mg} / \mathrm{m}^{3}$ & ppm & $\mathrm{mg} / \mathrm{m}^{3}$ & \\
\hline Carbon dioxide & $\mathrm{CO}_{2}$ & 5,000 & 9,000 & 30,000 & 54,000 & [124-38-9] \\
\hline $\begin{array}{l}\text { Hydrogen } \\
\text { bromide }\end{array}$ & $\mathrm{HBr}$ & $\mathrm{C} 2$ & C 6.62 & - & - & [10035-10-6] \\
\hline $\begin{array}{l}\text { Hydrogen } \\
\text { chloride }\end{array}$ & $\mathrm{HCl}$ & 1 & 1.5 & 2 & 3 & {$[7647-01-0]$} \\
\hline $\begin{array}{l}\text { Nitrogen } \\
\text { dioxide }\end{array}$ & $\mathrm{NO}_{2} / \mathrm{N}_{2} \mathrm{O}_{4}$ & 3 & 6 & 5 & 10 & [10102-44-0] \\
\hline Sulfur dioxide & $\mathrm{SO}_{2}$ & 2 & 5 & 5 & 10 & [7446-09-5] \\
\hline Ammonia & $\mathrm{NH}_{3}$ & 25 & 18 & 35 & 27 & [7664-41-7] \\
\hline $\begin{array}{l}\text { Carbon } \\
\text { monoxide }\end{array}$ & $\mathrm{CO}$ & 30 & 34 & 200 & 229 & $\begin{array}{c}{[630-08-0]} \\
\text { Reproductive toxicity } 1 \mathrm{~A}\end{array}$ \\
\hline
\end{tabular}

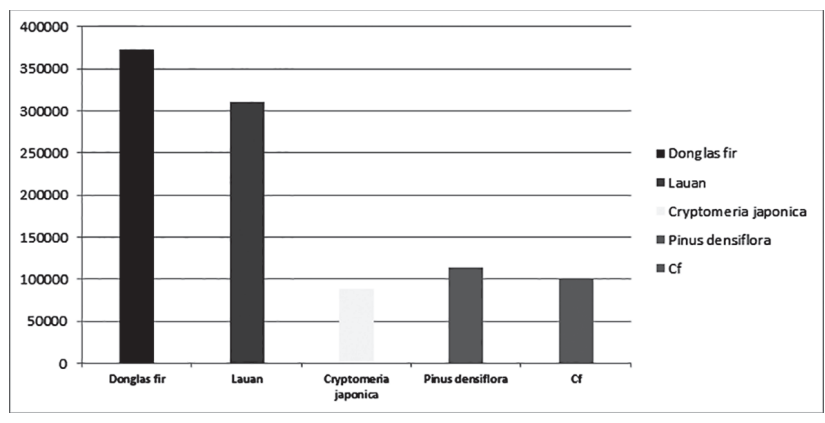

Fig. 14. Total amount of $\mathrm{CO}_{2}$ of wood materials.

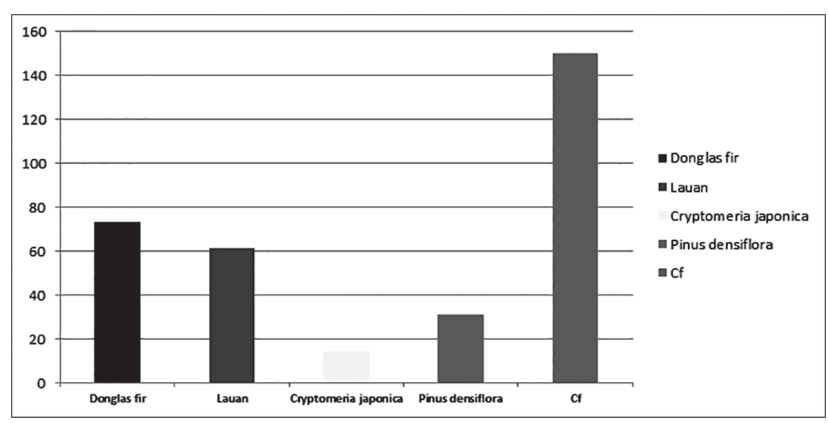

Fig. 15. Total amount of $\mathrm{HBr}$ of wood materials.

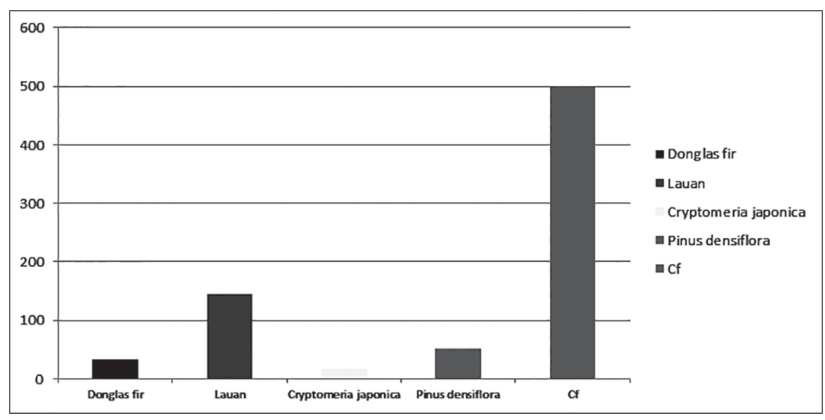

Fig. 16. Total amount of $\mathrm{HCl}$ of wood materials.

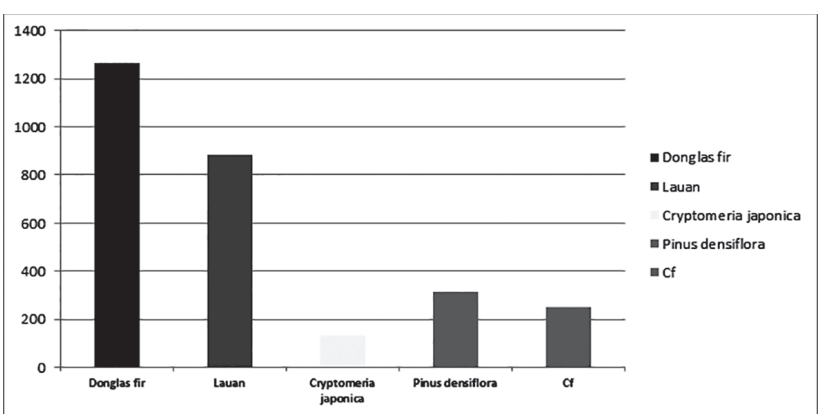

Fig. 17. Total amount of $\mathrm{NO}_{2}$ of wood materials.

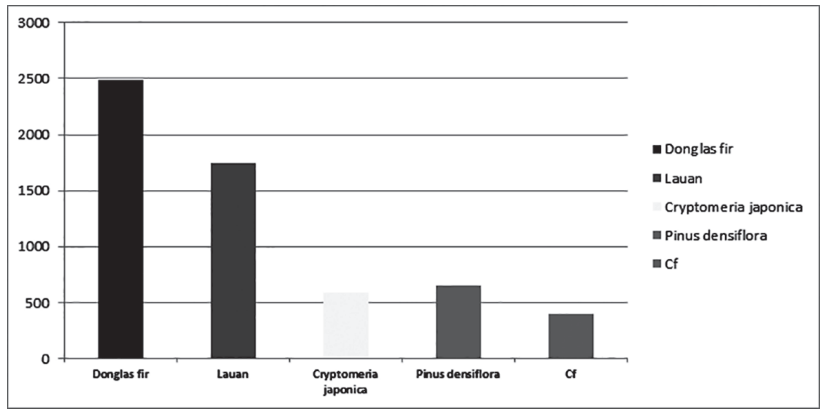

Fig. 18. Total amount of $\mathrm{SO}_{2}$ of wood materials.

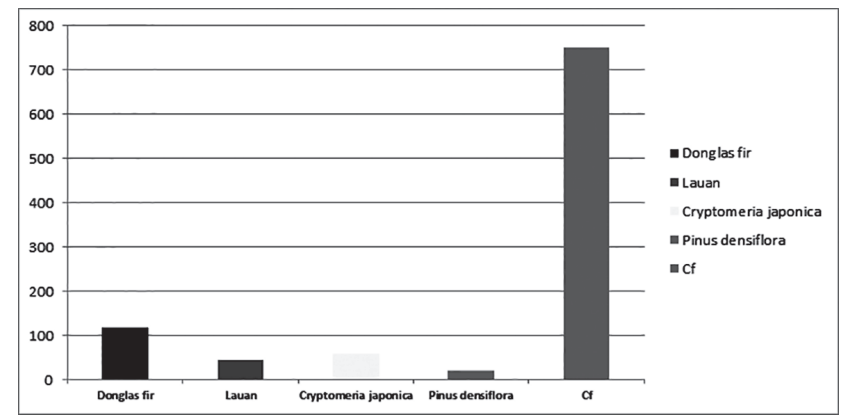

Fig. 19. Total amount of $\mathrm{NH}_{3}$ of wood materials. 


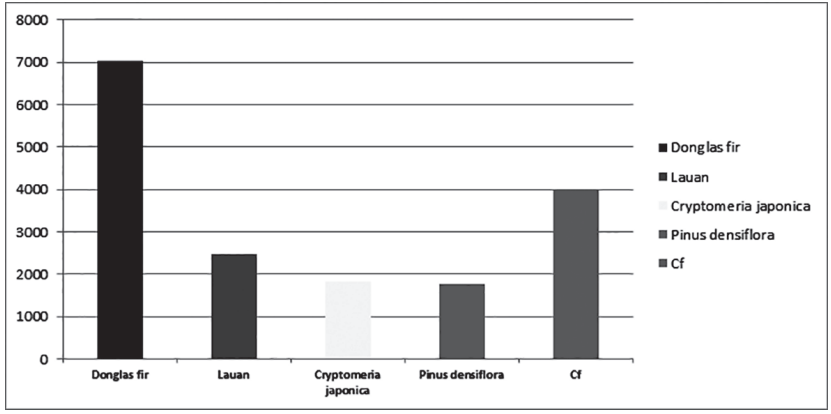

Fig. 20. Total amount of CO of wood materials.

respectively, exceeding the lethal concentration (Cf) 400 ppm. Figure 19 shows the ammonia (NH3) emissions, which are far below the lethal concentration 750 ppm across the board. Slash pine recorded the highest $\mathrm{NH}_{3}$ emission (116.596 ppm) followed by cedar (57.82 ppm), lauan (45.371 ppm) and pine (21.714 ppm) in the order named. Figure 20 shows the carbon monoxide (CO) emissions. The CO emission by slash pine $(7,021.683 \mathrm{ppm})$ exceeded its lethal concentration $4,000 \mathrm{ppm}$, whereas those of lauan $(2,477.809 \mathrm{ppm})$, cedar $(1,826.369 \mathrm{ppm})$ and pine $(1,777.042 \mathrm{ppm})$ were lower than the lethal concentration $4,000 \mathrm{ppm}$. Table 4 shows the workplace exposure limits of hazardous gases involving TWA (Time Weighted Average) and STEL (Short Term Exposure Limit). The analysis of the hazard assessment of the wood materials in this study substantiates the harmful effects of the gases on human body, which is consistent with previous findings (Lee D. H., Y. K., Kong 2005; Kim S. S., et al., 2011; Seo H. J., D. W. Son 2015).

Also, Table 5 presents the health risk assessment of the observed 7 gases based on the exposure standards and health risks prescribed in the Material Safety Data Sheets (MSDS) (KOSHA, 2017). As shown in Figure 14, the $\mathrm{CO}_{2}$ concentrations detected in slash pine and lauan were over three times higher than its lethal concentration 100,000 ppm, far exceeding those in cedar and pine. The $\mathrm{CO}_{2}$ concentrations of the materials tested in this study far exceeded the local exposure standards for chemicals and the biological exposure standards specified in the MSDS, i.e. TWA: 5,000 ppm and STEL: 30,000 ppm. According to the IUCLID referred to in the MSDS, the inhalation of mist LC $5050,000 \mathrm{ppm} \sim 30,000 \mathrm{ppm}$ by laboratory rats caused such reproduction toxicity as congenital malformation of the heart, heart lesions, ventricular septal defect, fertilization and deformity toxicity, spinal deformity, nerve root defect on rear feet, adaptive behavior disorder, weight loss metabolic stress, vital temperature and blood pressure falls, increasing blood flow velocity, decreasing respiration rates, depression and mental dysfunction) (KOSHA, 2017). As shown in Figure 15 , the hydrogen bromide $(\mathrm{HBr})$ emissions by slash pine and lauan were less than half its lethal concentration $150 \mathrm{ppm}$. According to the MSDS, hydrogen bromide $(\mathrm{HBr})$ is a highly corrosive substance, and causes severe burns and damage upon contact with eyes, skin and respiratory system as well as pulmonary edema. Rats repeatedly exposed to a toxic substance related to $\mathrm{HBr}$, phosphorous tribromide, for 28 days developed chemical change in serum, hematologic change and mild infection in nasal cavity (Cho N. W., et al., 2012).

As shown in Figure 16, the hydrogen chloride ( $\mathrm{HCl})$ concentrations were below its lethal concentration 500 ppm, with that of lauan being 145.918 ppm. According to the MSDS data, laboratory rabbits exposed to HCI developed severe eye damage and skin corrosion, while humans developed bronchial spasm and asthma. Also, in humans, inhalation of HCI led to dyspnoea, laryngitis, bronchitis, bronchoconstriction, pneumonia, upper airway edema, inflammation, necrosis and pulmonary edema, whereas laboratory animals suffered mucosa necrosis secondary to bronchitis, pulmonary edema, bleeding, thrombus and bronchial pulmonary dysplasia. The repeated exposure to HCI led to tooth erosion and damage and recurrent chronic bronchitis in humans. Blood urea and urine urea decreased while ammonia extracted from urine increased in 4 people who ingested $50 \mathrm{mM} /$ day for 4 days (KOSHA, 2017).). As shown in Figure 17, the nitrogen oxide $\left(\mathrm{NO}_{2}\right)$ concentrations were $1,265.3 \mathrm{ppm}$ in slash pine, $881.8 \mathrm{ppm}$ in lauan and $315.75 \mathrm{ppm}$ in pine, or 1.52 .5 times higher than its lethal concentration $250 \mathrm{ppm}$.

This finding paralleled Wilkins (Wilkins E., F. Murray, 1980) that reported nitrogenous compounds including nitric acid gas were emitted by burning woods via the pyrolysis of the wood extracts. $\mathrm{NO}_{2}$ is a reddish brown gas and has specific target organ toxicity (single exposure), affecting the pulmonary function leading to pulmonary edema in exposed humans. Also, NO2 has HSDB specific target organ toxicity (repeated exposure) with the prolonged exposure causing pulmonary diseases and decreasing resistance to infections in humans, whilst the repeated inhalation exposure affected the lung, decreasing immunity in laboratory animals(KOSHA 2017). To inhibit the production of nitrogen oxide including nitrogen dioxide $\left(\mathrm{NO}_{2}\right)$, it is effective to reduce air supply or temperature during combustion (Terrill J. B., et al., 1987).

As shown in Figure 18, the sulfur dioxide $\left(\mathrm{SO}_{2}\right)$ concentrations of the four materials substantially exceeded its lethal concentration. The $\mathrm{SO}_{2}$ concentrations of slash pine and lauan were 6 and 4 times higher than the lethal concentration $400 \mathrm{ppm}$. Also, those of cedar and pine exceeded the lethal concentration. $\mathrm{SO}_{2}$ has specific target organ toxicity (single exposure). In an inhalation exposure test, guinea pigs, dogs, rabbits and white rats suffered irritation of airway mucosa, increased airway resistance and loss of airway cilia, whilst humans suffered declining respiratory functions including increasing airway resistance and developed pulmonary edema, when inhaling high concentrations of $\mathrm{SO}_{2}$. As shown in Figure 19, the ammonia $\left(\mathrm{NH}_{3}\right)$ concentrations in the materials fell within the range of $21.7 \mathrm{ppm} \sim 116.6 \mathrm{ppm}$, which were much lower than the lethal concentration 750 ppm. Ammonia is a colorless irritative gas. A $12 \%$ ammonia solution caused skin corrosion and severe eye damage. As an irritative and corrosive substance, NH3 
caused eye corrosion, respiratory hypersensitivity, asthma and asthmatic symptoms in humans (KOSHA 2017). As shown in Figure 20, the carbon monoxide (CO) concentration in slash pine is nearly twice as high as the lethal concentration $4,000 \mathrm{ppm}$.

The CO emissions by lauan, cedar and pine were nearly half the lethal concentration. The chemical and biological exposure standards of CO are TWA:30 ppm and STEL: 200 ppm in Korea. In a reproductive and developmental toxicity study as per the Ministry of Employment and Labor's Notification 1A and OECD TG 414 , maternal toxicity was not observed in mice inhaling $\mathrm{CO}$, whereas fetal weight loss was observed. Also, the mean perinatal mortality or fetal resorption was greater than that of the control group. In terms of the specific target organ toxicity (single exposure), the inhalation exposure increased the blood carboxyhemoglobin level, which affected the nervous and circulating systems of humans and animals and decreased mental capacity, mobility and hearing. In addition, in an acute inhalation toxicity study as per the OECD TG 403, all animals became unconscious. In a specific target organ toxicity study with repeated inhalation (repeated exposure), the cardiovascular system was affected in animals. In a chronic inhalation toxicity test with rats exposed to 50 250-ppm concentrations pursuant to the OECD TG 452, the carbon monoxide hemoglobin ( $\mathrm{COHb}$ ) level rose higher than that of the control group, and its effects on heart weights were observed(KOSHA 2017).

Cho et al. (Cho N. W., et al., 2012) investigated the toxicity of four gas-phase substances $(\mathrm{HCl}, \mathrm{HF}, \mathrm{HCN}$ and $\mathrm{SO}_{2}$ ) and their impacts on health using laboratory mice, and observed a pigmental macrophage in end and respiratory organs and adjacent pulmonary alveoli at medium to high concentration levels, local hyperemia and congestion (central vein and portal sace) in the liver at low, medium and high concentration levels, hepatolysis specific to a high concentration level, small-vessel hyperemia and congestion in the spleen and thymus at the highest concentration level, renal tuft, proximal and distal tubule congestion in the kidney at low to high concentration levels, severe damage in lung and heart tissues, and notably the severest tissue damage in HCN (Cho N. W., et al., 2012). Above all, the lethal concentrations ( $\mathrm{Cf}$ ) of carbon dioxide $\left(\mathrm{CO}_{2}\right)$, nitrogen dioxide $\left(\mathrm{NO}_{2}\right)$, sulfur dioxide $\left(\mathrm{SO}_{2}\right)$, ammonia $\left(\mathrm{NH}_{3}\right)$ and carbon monoxide (CO) were higher in slash pine and lauan than those of cedar and pine. Also, $\mathrm{CO}_{2}$ and $\mathrm{CO}$ emissions substantially surpassed the other gases across the materials tested in this study, which agrees with a previous report that the $\mathrm{CO}_{2}$ and $\mathrm{CO}$ emissions from the combustion of cellulose composed of carbon composite materials were approximately 90\% higher than other gas emissions (Kim D. H., et al., 2009). The findings of this study demonstrated the inhalation and prolonged accumulation of the hazardous gases emitted by the combustion of the materials tested here could develop into fatal diseases.

\section{CONCLUSION}

This study analyzed the structures and combustion gases of four wood materials used for buildings, i.e. slash pine, lauan, cedar and pine, and proposed some reference data conducive to assessing their health hazards in fires. The findings highlighted the following:

1. The different forms of carbonized woods are attributable to the differences in wood types, distribution density (specific gravity) of medullary rays, and water content among the tree species.

2. The carbon dioxide $\left(\mathrm{CO}_{2}\right)$ emissions by slash pine (373,149.9 ppm) and lauan (310,142.5 ppm) were 3.7 and 3 times higher than the lethal concentration (Cf) $100,000 \mathrm{ppm}$.

3. The nitrogen dioxide $\left(\mathrm{NO}_{2}\right)$ emissions by slash pine $(1,265.303 \mathrm{ppm})$ and lauan (881.791 ppm) were 5 and 3.5 times higher than the lethal concentration (Cf) $250 \mathrm{ppm}$, whilst the $\mathrm{NO}_{2}$ concentration in pine (315.75 ppm) was marginally higher than the lethal concentration.

4. The sulfur dioxide $\left(\mathrm{SO}_{2}\right)$ emissions by slash pine $(2,485.306 \mathrm{ppm})$ and lauan $(1,743.776 \mathrm{ppm})$ were 6 and 4 times higher than the lethal concentration (Cf) $400 \mathrm{ppm}$, whilst those by pine $(654,921 \mathrm{ppm})$ and cedar $(585,816 \mathrm{ppm})$ were moderately higher than the lethal concentration.

5. The carbon monoxide (CO) emission by slash pine $(7,021.683 \mathrm{ppm})$ was twice as high as the lethal concentration (Cf) 4,000 ppm in contrast to those of the other materials.

6. With reference to the lethal concentrations (Cf) and MSDS, the exposure to significant amounts of a range of gases emitted by the combustion of the wood materials tested here is highly likely to cause asthmatic symptoms linked to bronchial spasm, respiratory distress, laryngitis, bronchitis, bronchoconstriction, pneumonia, upper airway edema, inflammation, necrosis, pulmonary edema, tooth damage, chronic bronchitis, declining resistance to infections, and increasing blood carboxyhemoglobin, which affects the nervous and circulating systems of humans and animals and deteriorates mental capacity, mobility and hearing.

\section{AUTHOR CONTRIBUTIONS}

Y. J. PARK designed the research, experimental design and experimental supervision were conducted for experimental study. S. Y. LEE wrote an English paper, experimental supervision was carried out. J. B. KIM performed FT-IR experiments on combustion gas experiments. and S. OHGA designed the study, supervised the research. All authors assisted in editing the manuscript and approved the final version.

\section{ACKNOWLEDGEMENTS}

This research was supported by Basic Science Research Program through the National Research 
Foundation of Korea (NRF) funded by the Ministry of Education (No. 2016R1D1A1B02008374).

\section{REFERENCES}

Cho N. W., D. H. Lee and E. H. Oh, "A Toxicity Evaluation for the Toxic Gases of Building Finish Materials", J. of Korean Oil Chemists' Soc., Vol. 29, No. 1, pp. 129-130, (2012)

Jung H. S., H. Y. kang, J. H. Park, N. H. Lee, H. W. Lee, C. W. Lee, C. W. kang and H. M, Yo, 'Latest timber drying' Seoul National Univ. Publishing, pp. 12-14, (2005)

Kim D. H., E. S. Kim and M. B. Lee, "Combustion Emission Gas Analysis and Health Hazard Assessment about P. densiflora and Q. variabilis Surface Fuel Beds", J. of Korean Institute of Fire Sci. \& Eng. Vol. 23, No. 5, p 24, (2009)

Kim D. H., E. S. Kim and M. B. Lee, "Combustion Emission Gas Analysis and Health Hazard Assessment about P. densiflora and Q. variabilis Surface Fuel Beds", J. of Korean of Fire Sci. \& Eng. Vol. 23, No. 5, pp. 28-29, (2009)

Kim J. B. and S. Y. Lee, "Toxicity Evaluation of the Combustion Products from Synthetic Wood as Internal Finish", J. of Korean Institute of Fire Sci. \& Eng. Vol. 30, No. 2, pp. 7-18, (2016)

Kim S. S., N. W. Cho and D. H. Rie, "A Research for Assessment Fire Toxic Gas of Construction Material Using FT-IR and FED", Journal of Korean Institute of Fire Sci. \& Eng. Vol. 25, No. 6, pp. 27-31, (2011)

Kim Y. T., 'Study on combustion characteristics of auto motive interior', kangwon National Univ, Graduate School of Science and Industry Major Disaster Management, pp. 22-23, (2010)

Kim J. B. and S. Y. Lee, "The Combustion Gas Hazard Assessment of Main Building Materials", J. Korean Wood Sci. Technology. Vol. 44, No. 5, pp. 639-654, (2016)

KOREA Occupational Safety \& Health Agency(KOSHA) MSDS CAS No, (2017)
KS F 2271, Built in Flame retardant Building Materials, Test Methods and Structures, Korea Standards Association, (1998)

Kwon H. S., "A study on the fire death through the fire cases", Seou fire academy, Fire Research, Vol. 13, pp. 229-230, (2011)

Lee D. H. and Y. K. Kong, "A study on combustion gas toxicity of polymeric materials using FTIR gas analysis", Korean Society of Hazard Mitigation Vol. 5, No. 4, pp. 79-84, (2005)

Moon Y. S. and S. R. Park, Interior Architecture, Book publishing, Kongiwon, pp. 18-19, (2016)

MPSS(Fire Statistical Yearbook, Ministry of Public Safety and Security), p. 84,86, (2016)

NES 713, Determination of the Toxicity Index of the Products of Combustion from Small Specimens of Materials. U. K. Ministry of Defence Naval Engineering Standards, Foxhill Bath, U.K, (1985)

Pearce F. M. and Y. P. Khanna, D. Raucher,"Thermal Characterization of Polymeric Materials". Chap. 8, Academic Press, New York, U.S.A, (1981)

Seo H. J. and D. W. Son, "Hazard Assessment of Combustion Gases from Interior Materials", J. of Korean Institute of Fire Sci. \& Eng. Vol. 29, No. 4, p. 49, (2015)

Seo H. J. and D. W. Son, "Hazard Assessment of Combustion Gases from Interior Materials", Fire Sci. Eng., Vol. 29, No. 4, pp. 49-56, (2015)

Spearpoint M. J., "Predicting the ignition and buring rate of wood in the cone calorimeter using an intergral model", 30, NIST GCR, pp. 99-775, U.S.A, (1999)

Terrill J. B., R. R. Montgomery and C. F. Reinharde, "Toxicity Evaluation of Fire Effluent Gases from Experimental Fires in a Building", J. of Korean of Fire Sci. \& Eng. Vol. 5, No. 4, pp. 248 271, (1987)

Wilkins E. and F. Murray, "Toxicity of Emissions from Combustion and Pyrolysis of Wood", Wood Science and Technology, Vol. 14 pp. 281-288, (1980) 